\title{
Conceptual Design of a Medium-Sized Combined Smart Photovoltaic - Agriculture System - Case Study in Malaysia
}

\author{
Harijono Djojodihardjo ${ }^{a}$ \\ President, The institute for the Advancement of Aerospace Science and Technology (IAAST), Jakarta 15419, \\ Indonesia
}

\begin{abstract}
With the backdrop of sustainable environment, Photo-Voltaic Power System linked to Climate-Smart Agriculture may offer solutions for Sustainable Energy, Climate Change mitigation and Sustainable Agriculture. An overview of the scope, extent and options of such combined - Co-Located PV Agricultural System appropriate for South East Asian setting, in particular, Malaysia and Indonesia is elaborated, for preliminary insight on steps and choices that have to be taken in undertaking such venture. Possible photovoltaic (PV) system installation and estimate the cost, performance, and site impacts of different PV options are discussed. Technical, financing and procedural aspects that could assist in the implementation of a Co-located PV system at the site should then be studied for decision options. A brief Framework for Conceptual Design of Co-Located PV-Agricultural System Plant is outlined.
\end{abstract}

\section{Introduction}

Sustainable growth and the sustainability of the environment, and more pronouncedly, global changes, are not only the concern of governments and international organizations, but for each and every individuals. Energy, food security, poverty and climate change are closely linked sustainable development. Climate-Smart Agriculture is a very significant part of the solution for both Climate Change mitigation and Sustainable Agriculture. Agriculture has much to contribute to a low emissions development strategy. Climate-smart agriculture is essential for building capacity, experience and guiding future choices, as well as smart management of natural resources [1,2]. Climate-smart agriculture is closely related to sustainable energy. Accordingly, to address sustainable energy and climate-smart agriculture relevant for sustainable development on the macro scale, and economical sustainable energy in the micro scale, the present work reviews and summarizes relevant aspects on the state of the overriding considerations and then present a preliminary concepts of Combined Smart /Co-Located Photovoltaic - Agriculture System, appropriate for South East Asian setting, in particular, Malaysia, as a case study. Furthermore, the purpose of this paper is to provide an overview of the scope and extent of such combined - Co-Located PV Agricultural System, for preliminary insight on steps and choices that have to be taken in undertaking such venture. A comprehensive assessment on the site for a possible photovoltaic (PV) system installation and estimate the cost, performance, and site impacts of different PV options would be the follow up of the decision choices. Financing options

\footnotetext{
${ }^{a}$ Corresponding author : harijono.djojodihardjo@yahoo.com 
that could assist in the implementation of a PV system at the site are discussed for decision options. A brief framework for conceptual design of Co-Located POV-Agricultural System Plant is outlined.
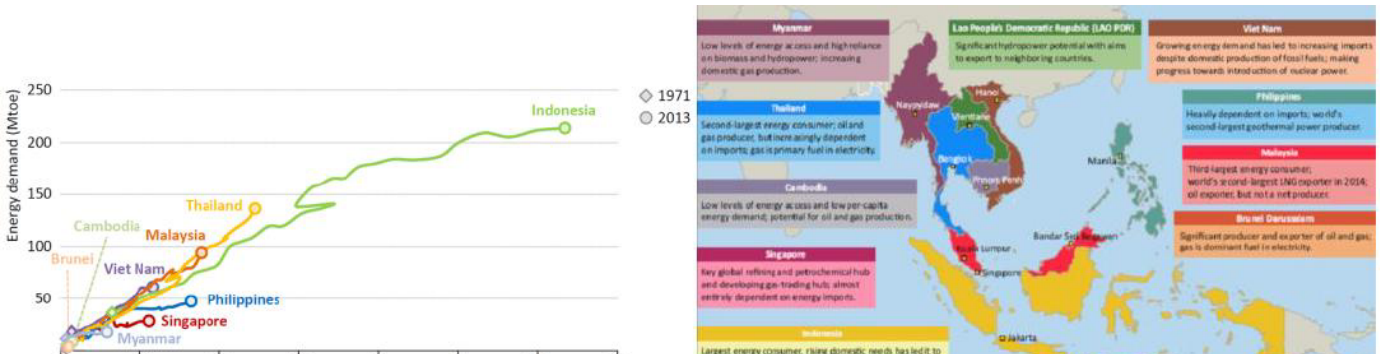

Figure 1: (a) Total primary energy demand and GDP in selected Southeast Asian countries, 1971-2013 [3,4]; (b) Energy demand prospects [4].

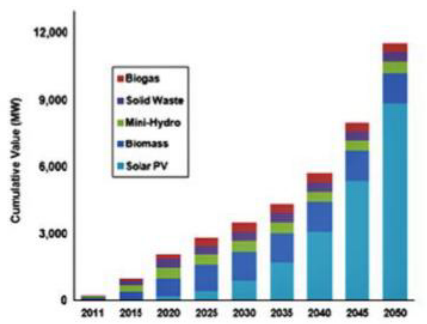

(a)

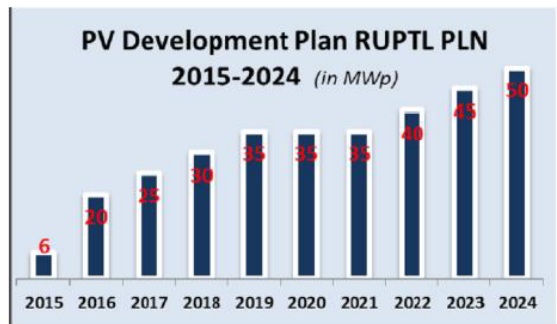

(b)

Figure 2: (a) Potential cumulative values of RE installed capacity in Malaysia for the period (2011-2050)[5]; (b) PV Development Plan, 2015-2024, Indonesia [6].

The focus of the present paper is on the ASEAN region, as one of the fastest developing regions in the world which requires rising energy supplies for their rapid economic development growth. Since Southeast Asia's energy use and economic growth gradually decouple, driven by the adoption of more efficient technologies, increasing saturation of appliances and equipment in some markets, and as the economic structure shifts to less energy-intensive activities [5], this ratio is expected to gradually decline over time. The energy demand evolution is illustrated in Fig. 2, which summarizes the potential cumulative values of Renewable Energy installed capacity in Malaysia for the period (20112050)[5,7] and Indonesian PV Development Plan, 2015-2024 [6].

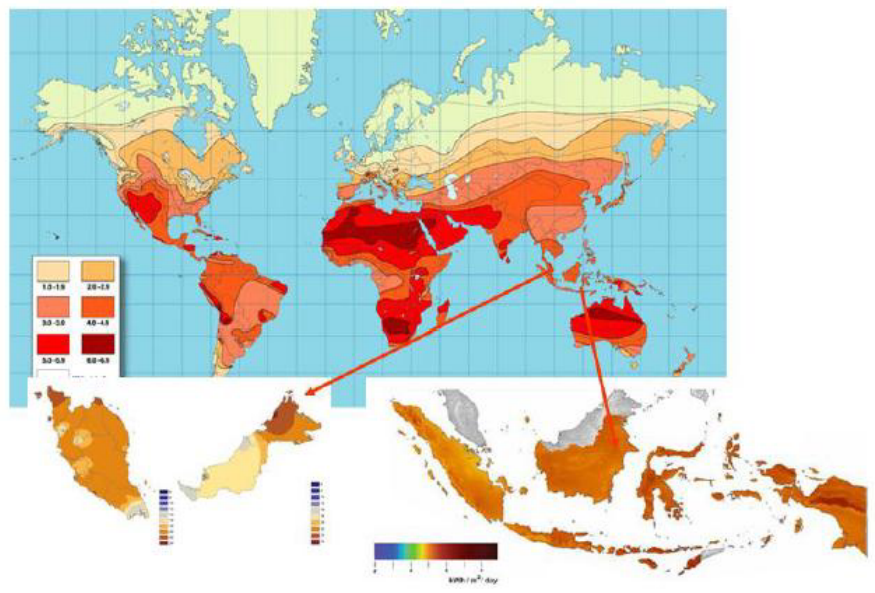

Figure 3: Solar Irradiation in Malaysia and Indonesia in $(\mathrm{MJ} / \mathrm{m} 2 /$ day) in the backdrop of Global Radiation in (synthesized from [7] and [8]). 


\section{Solar Photo Voltaic applications in Malaysia and Indonesia}

To illustrate the dedicated application of Photo Voltaic Solar Energy, in 1998, Tenaga Nasional Berhad (TNB) in Malaysia has installed grid-connected PV systems for National power utility [7]. Six pilot grid-connected PV systems were installed with power capacity ranging from $2.8 \mathrm{kWp}$ to 3.8 $\mathrm{kWp}$ in 1998. first grid-connected PV system was installed by Tenaga National Research (TNR) Sdn. Bhd. on the rooftop of the College of Engineering, University Tenaga Nasional (UNITEN) with the system capacity of $3.15 \mathrm{kWp}$ [7]. Next two grid-connected photovoltaic systems were installed, one at a BP petrol station with the capacity of $8 \mathrm{kWp}$ by BP Malaysia while the other one was installed at Solar Energy Research Park in University Kebangsaan Malaysia (UKM) with a capacity of $5.5 \mathrm{kWp}$. One of the objectives of these initiatives is to introduce energy savings in the area of high rise buildings construction and design through air flow improvement. Integrated installation of PV system in a building can improve energy efficiency of a building through meticulous air flow improvement, eventhough the building is tightly sealed to the outside. Prototype Solar House (PSH) has been designed and built in order to emphasize the multifunctional aspects of PV in buildings for living house at urban areas in the country [7]. In 2000, the first Malaysian Building Integrated Photovoltaic (BIPV) system was installed in Port Dickson Malaysia with the capacity of $3.15 \mathrm{kWp}$. By November 2000, another BIPV system was installed in Shah Alam Malaysia with a capacity of $3.24 \mathrm{kWp}$.
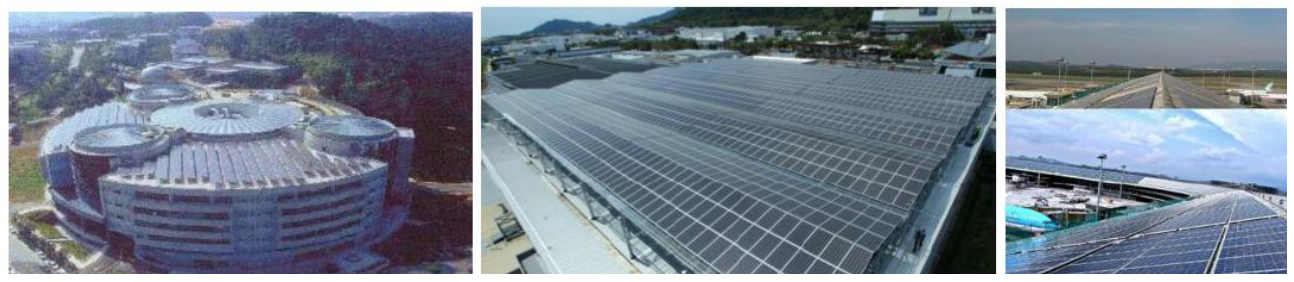

Figure 4: Some Examples of Solar PV Power Plant Installed in Malaysia; (a) $362 \mathrm{kWp}$ Building Integrated Solar Photovoltaic System at PV system Technology Park Malaysia; (b) $646 \mathrm{kWp}$ Building Integrated (Roof-Top) Integrated Solar PV Power Plant at Robert Bosch (M) Sdn Bhd, Penang, Malaysia; (c) 19 MWp Kuala Lumpur International Airport, combined ground-mount, parking canopy and rooftop PV systems.

The installations, being a standalone system, were fixed on the top of existing roof tiles and appeared to be successful since it is functioning without any problem in maintenance of the unit $[9,10]$. Some PV Power Plants that have been installed in Malaysia recently are exhibited in Fig. 4.

\section{Co-Located PV system plants imperatives}

In a recent shift towards Grid-Connected Systems, at the end of 2008, cumulative installed PV capacity totaled more than 14 gigawatts (14,000 megawatts) worldwide, according to the International Energy Agency (IEA)[4,11].

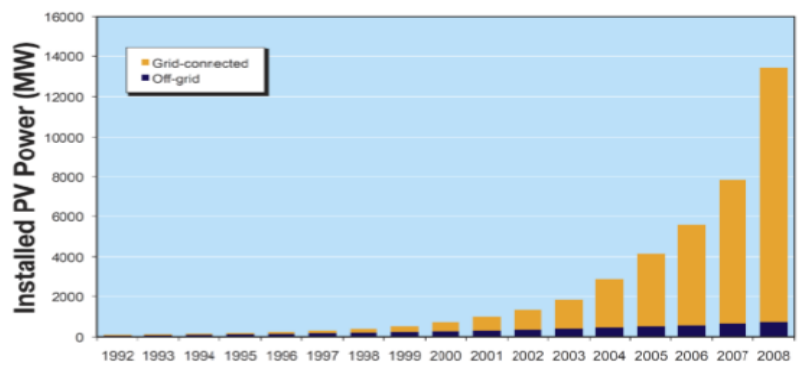

Figure 5: Worldwide Grid-Connected and Off-Grid PV Power [4,11]. 


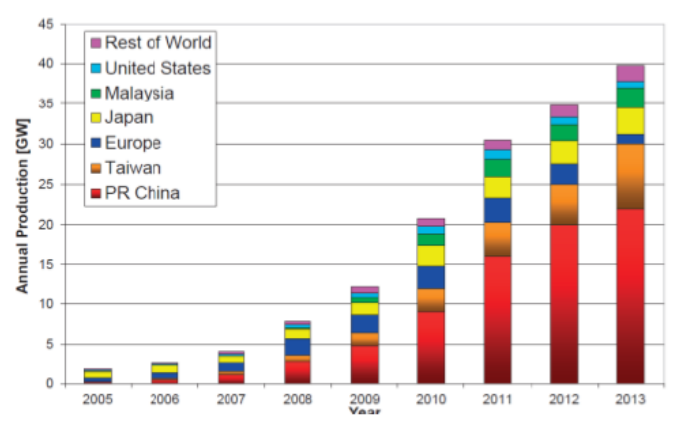

Figure 6: World PV cell/module production from 2005 to 2013 (extracted from [12])

Approximately $5.5 \mathrm{GW}$ of PV was installed in 2008, an increase of about $140 \%$ over the previous year. The IEA data clearly indicate tremendous growth in grid-connected PV since the mid 1990s when it was the minority of the market. This trend has continued such that grid-connected applications accounted for about $94 \%$ of cumulative installations by 2008 . Off-grid applications have continued to grow worldwide, although less vigorously than grid-connected systems.

Fig. 6 illustrates the growth in PV capacity for both off-grid and grid-connected applications. Based on market and policy considerations, grid-connected PV systems for commercial, industrial, and residential uses appear to be entering a period of long-term, accelerated growth after recovery from recession of 2009's. Fig. 5 shows the World PV cell/module production from 2005 to 2013 (extracted from [12]).

\subsection{Vegetation-Centric Approaches to Co-Location}

Vegetation-centric approaches to co-location of solar energy and vegetation are characterized by actions that serve to maximize biomass production activities and minimize changes to existing vegetation management activities, while also incorporating solar energy production activities. Vegetation-centric approaches may be well suited to areas that are land constrained or that are already developed agricultural areas. The basic premise is that the vegetation productivity of the land being utilized is not sacrificed for the sake of solar generation. An example of Vegetation-Centric Approach to PV System Co-Location is exhibited in Fig. 7

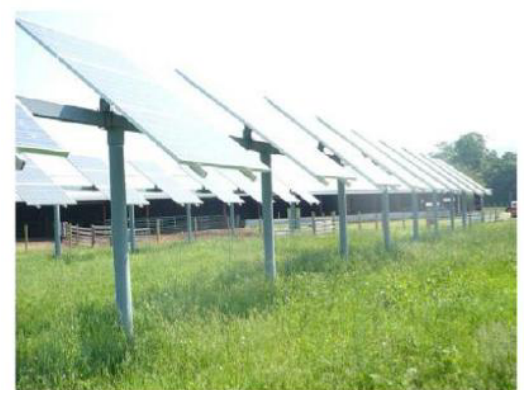

Figure 7: (a) Pasture crops growing under elevated PV panels in Massachusetts. Photo from Stephen Herbert, University of Massachusetts [13].

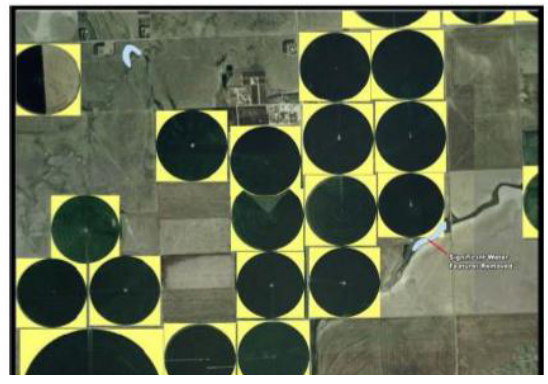

Figure 8: Center-pivot irrigation envelopes with irrigated lands. Yellow areas show unused and nonirrigated lands that could be sites for solar energy technologies[13].

\subsection{Energy-Centric Approaches to Co-Location}


Energy-centric approaches to co-location of solar energy developments and vegetation are characterized by actions that serve to maximize solar energy output, minimize changes to solar development standard practices, while also promoting vegetation growth under and around the solar installation. Ideally, energy-centric approaches to co-location do not lead to a reduction in expected solar energy output. Energy-centric approaches may be well suited to areas with high quantities of land targeted for solar energy development or areas where solar development has already occurred. An example of Energy-Centric Co-Location of PV panels and vegetation at NREL site is exhibited in Fig. 8. Fig. 9 exhibits some examples of various PV Plants recently installed in Malaysia and Indonesia.

\begin{tabular}{|c|c|c|c|c|c|c|c|c|c|c|c|}
\hline No & \begin{tabular}{|l|l|} 
Type/ Place \\
\end{tabular} & $\begin{array}{l}\text { Solar } \\
\text { Radiati } \\
\text { on, } \\
\text { kWh/m } \\
2\end{array}$ & $\begin{array}{l}\text { Scale } \\
\text { capacit } \\
\text { a, kW } \\
\text { or MW }\end{array}$ & $\begin{array}{l}\text { Invest } \\
\text { ment, } \\
\text { RM }\end{array}$ & $\begin{array}{l}\text { Prorate } \\
\text { dorvest } \\
\text { Invest } \\
\text { ment k } \\
W\end{array}$ & \begin{tabular}{|l|l} 
Retum \\
for PV \\
Efficie
\end{tabular} & & $\begin{array}{l}\text { Annual } \\
\text { RM }\end{array}$ & venue & $\begin{array}{l}\text { Annual } \\
\text { Output } \\
\mathrm{kWh} / \text { year }\end{array}$ & \\
\hline 1 & Rooffopl & 1,571 & 5.28 & 52,800 & 10,000 & \begin{tabular}{|l|}
15 \\
4.55
\end{tabular} & $\frac{20}{3.37}$ & $\frac{15}{12,133}$ & $\frac{20}{16,177}$ & $9,975^{*}$ & "based on $350 \times$ daily output; \\
\hline 2 & \begin{tabular}{|l|l|} 
Columba \\
Rooflop/Aqu
\end{tabular} & 1,571 & $\frac{6 \mathrm{~W}}{5.78}$ & 57,800 & 10,000 & 4.84 & 3.59 & 12,516 & 16,688 & $10,290^{*}$ & \\
\hline 3 & 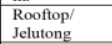 & 1,571 & $4.8 \mathrm{~kW}$ & 48,000 & 10,000 & \begin{tabular}{|l|l|}
11.19 \\
\end{tabular} & 8.17 & 4,768 & 6,357 & $3,920^{*}$ & \\
\hline 4 & \begin{tabular}{|l|l|} 
PV system \\
Technology \\
Park \\
Malaysia
\end{tabular} & & $\begin{array}{l}362 \\
k w_{p}\end{array}$ & 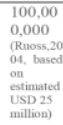 & $\begin{array}{l}27,624 . \\
3\end{array}$ & & & & & & \\
\hline 5 & \begin{tabular}{|l} 
Robert \\
Bosch (M) \\
Son Bhd, \\
Penang, \\
Malaysia
\end{tabular} & & $\begin{array}{l}646 \\
k w_{p},\end{array}$ & & & & & & & & \\
\hline 6 & \begin{tabular}{|l|} 
PV power \\
plant tat \\
Paiam, \\
Palaysia by \\
cypark \\
Resources \\
Berhad \\
\end{tabular} & & $8 \mathrm{MW}$ & & & & & & & & \\
\hline 7 & 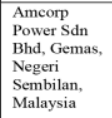 & & $\begin{array}{l}l_{10.25} \\
\text { MW }\end{array}$ & & & & & & & & \\
\hline 8 & 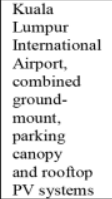 & & $\begin{array}{l}19 \mathrm{MW} \\
\text { (DC) }\end{array}$ & & & & & & & & \\
\hline 9 & 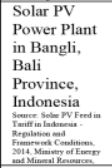 & & $1 \mathrm{MW}$ & $\begin{array}{l}-2,000, \\
\text { ooo-- } \\
\text { (IIRR } \\
26 \\
\text { billion) }\end{array}$ & & & & & & & \\
\hline 10 & $\begin{array}{l}\text { ADB } \\
\text { sponsored } \\
\text { Solar energy } \\
\text { panels ing } \\
\text { Sumban } \\
\text { island }\end{array}$ & & & & & & & & & & \\
\hline
\end{tabular}

Figure 9: Summary of some PV Plants Examples in various categories

\section{Preliminary conceptual design of Co-Located PV-Agricultural system}

Basic Configuration. An more detailed elaboration of the conceptual design described here should be made, based on in depth study for practical implementation like Small Scale Experiment for Technology and Model Identification, Feasibility Study and Collateral Assurances, Site selection and Land Requirements of Solar Energy Installations, as well as Land-Use and Environmental Impacts Study of Co-Located PV-Agriculture System Projects.

One option of the Co-Located PV Power system that can be proposed is exhibited in Fig. 10, following the configuration of Pasture crops growing under elevated PV panels as example. Its 
capacity can be chosen between $300 \mathrm{KWp}$ to $1 \mathrm{MWp}$. The circuitry schematics are reproduced on the right of this figure.

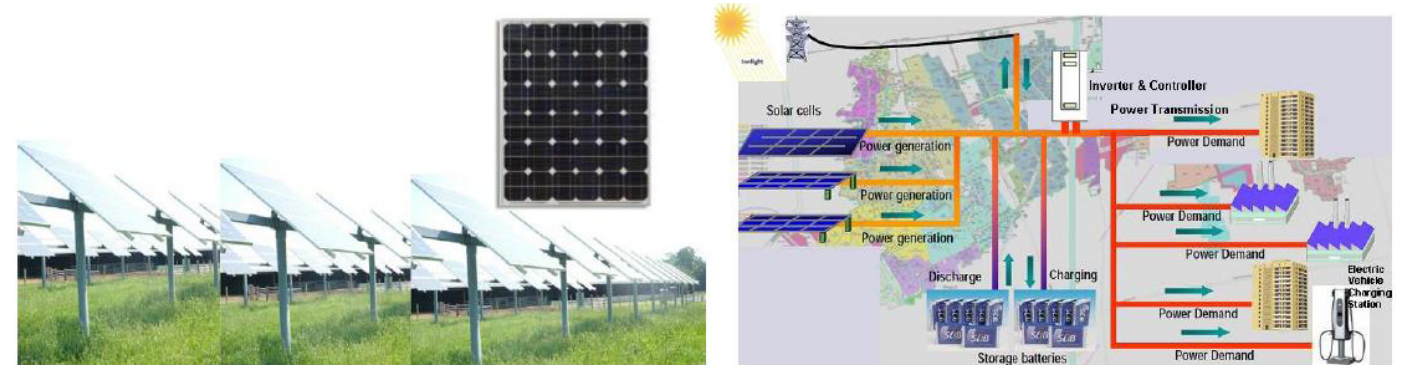

Figure 10: Configuration Option No.1, following Pasture crops growing under elevated PV panels example. Capacity can be chosen between 500KWp to $1 \mathrm{MWp}$. The circuitry schematics are shown on the right. Illustrated in the inset is the image of monocrystalline solar panels, which can be utilized.

Summary of Sample Design Sizing and the Calculation of the Number of PV Panels. The summary is given in Table.1.

Table 1: Sample Estimate of PV System Preliminary Design

\begin{tabular}{|c|c|c|c|c|c|c|c|c|c|}
\hline & $\begin{array}{l}\text { PV } \\
\text { Panels/row }\end{array}$ & $\begin{array}{l}\text { No.Rows/ } \\
\text { module }\end{array}$ & $\begin{array}{l}\text { Total No.PV } \\
\text { Panels/module }\end{array}$ & $\begin{array}{l}\text { Watts- } \\
\text { peak/PV Panel }\end{array}$ & $\begin{array}{l}\text { Total Power } \\
\text { (Watts-peak) }\end{array}$ & $\begin{array}{l}\text { Watts. } \\
\mathrm{m} 2\end{array}$ & $\begin{array}{l}\text { Price/Pan } \\
\text { el(estimat } \\
\text { e,MYR) }\end{array}$ & $\begin{array}{l}\text { Price PV } \\
\text { Panels } \\
\text { (MYR) } \\
\end{array}$ & \\
\hline & 600 & 5 & 3000 & & & & & & \\
\hline $\begin{array}{l}\text { Solar Panel } \\
100 \mathrm{Wp} \\
\text { Monocrystal } \\
\text { line }\end{array}$ & & & & & & & & & $\begin{array}{l}\mathrm{RM} \\
126.90\end{array}$ \\
\hline Equation 1 & \multicolumn{5}{|c|}{$\begin{array}{l}\text { Energy Generated }(\mathrm{kWh} / \text { day })=\text { Annual Solar Radiation } x \text { Sun Hours x PV } \\
\text { Efficiency x Area }\end{array}$} & & & & \\
\hline Equation 2 & \multicolumn{5}{|c|}{ Annual Revenue $=$ Energy Generated $\mathrm{x}$ Days in a Year $\mathrm{x}$ FiT rate } & & & & \\
\hline Equation 3 & \multicolumn{5}{|c|}{ Return of Investment = Initial Investment/ Net Annual Benefits } & & & & \\
\hline $\begin{array}{l}\text { Option 3, } \\
\text { PV Panels } \\
\text { Only, each } \\
100 \mathrm{Wp}\end{array}$ & & & & 100 & 300,000 & $\mathrm{pm}$ & 127 & 381,000 & $\begin{array}{l}1 \text { module, } \\
300,000 \\
\text { Watts- } \\
\text { peak }\end{array}$ \\
\hline $\begin{array}{l}3 \text { Modules, } \\
\text { PV Panels } \\
\text { Only }\end{array}$ & & & & & & & & $1,270,000$ & $\begin{array}{l}\sim 3 \\
\text { modules } \\
1 \mathrm{MW}- \\
\text { peak }\end{array}$ \\
\hline \multicolumn{2}{|c|}{ Initial Investment Cost } & \multicolumn{4}{|c|}{ PV Module+Inverter+Batteries+Installation cost + contingencies } & & & & \\
\hline \multicolumn{2}{|c|}{ Net Annual Benefits } & \multicolumn{4}{|c|}{ Revenue-Operation \& Maintenance Cost } & & & & \\
\hline \multicolumn{2}{|l|}{ Revenue } & \multicolumn{4}{|c|}{ Income from selling power to the utility } & & & & \\
\hline \multicolumn{2}{|c|}{$\begin{array}{l}\text { Operation and Maintenance } \\
\text { (O\&M) }\end{array}$} & \multicolumn{4}{|c|}{$\begin{array}{l}\text { Assumed to be } 1 \sim 2 \% \text { of the initial investment cost; can be } \\
\text { changed due to situation }\end{array}$} & & & & \\
\hline Inverter & & $\begin{array}{l}\text { SPM3000 } \\
\text { MS }\end{array}$ & $\begin{array}{l}3,000 \mathrm{MW}, \\
\text { Modified Sine } \\
\text { Wave }\end{array}$ & RM1,378.00 & US\$459.40 & & & & \\
\hline $\begin{array}{l}\text { Dee4p Cycle } \\
\text { Batteries }\end{array}$ & & $\begin{array}{l}\text { SPM100S } \\
\text { B }\end{array}$ & $\begin{array}{l}100 \mathrm{AH}, \\
12 \mathrm{~V}, \mathrm{AGM}\end{array}$ & RM772.00 & US257.40 & & & & \\
\hline Wiring & & & & & $\mathrm{US} 2.45 / \mathrm{m}$ & & & & \\
\hline \multicolumn{10}{|l|}{$\begin{array}{l}\text { Support } \\
\text { Frames }\end{array}$} \\
\hline \multicolumn{10}{|l|}{$\begin{array}{l}\text { Installation } \\
\text { Cost }\end{array}$} \\
\hline $\begin{array}{l}\text { Initial } \\
\text { Investment }\end{array}$ & $\mathrm{RM}$ & $4,125,000$ & $\begin{array}{l}\text { Prorated from } \\
\text { earlier Studies }\end{array}$ & $\begin{array}{l}\text { Payback } \\
\text { period, years }\end{array}$ & 4.258 & years & $\begin{array}{l}\text { Annual } \\
\text { Revenue }\end{array}$ & $\begin{array}{l}\text { Rough } \\
\text { Estimate } \\
676,363 \\
\end{array}$ & \\
\hline
\end{tabular}

\section{Concluding Remarks}

Based on an exhaustive review on Photo Voltaic Power System technology and Applications in various parts of the world, and particular applications in Malaysia and Indonesia, a comprehensive insight on conceptual design and technical requirements for an independent venture of Photo Voltaic Power System has been gained. Based on these, a conceptual design and preliminary configuration of a Co-Located Photovoltaic Agriculture system has been proposed, including the probable investment and rate of return. 


\section{References}

1. Djojodihardjo H. (1995). Perspective of Fifty Mega Watt Peak (50 MWp) Photovoltaic Solar Home System for Rural Electrification in Indonesia. Paper presented at UNESCO-BPPT-LIPI Round Table Conference on Solar Energy Jakarta, 1995.

2. Djojodihardjo, Aerospace Technology Vision for Green Energy, Paper ICSAFEI-189-24 August 2015, resented at the 7th Conference on Sustainable Food, Energy and Industry in Regional and Global Context, 25-27 August 2015

3. IEA, Southeast Asia Energy Outlook - WEO Special Report-IEA, 2013

4. IEA-Southeast Asia Energy Outlook - World Energy Outlook Special Report 2015

5. Ismail, A.M. et al, Progress of solar photovoltaic in ASEAN countries: A review, Renewable and Sustainable Energy Reviews, 2015

6. Abd.-Rosyid, Opportunities and Challenges For Solar PV Rooftop in Indonesia, BPPT, 2015

7. Mekhilef et al, Ismail, A.M. et al, Progress of solar photovoltaic in ASEAN countries: A review, Renewable and Sustainable Energy Reviews, 2015

8. Solar PV Atlas: Solar Power in Harmony with Nature, http://awsassets.panda.org/ downloads/solar_pv_atlas_final_screen_version_feb_2013.pdf

9. Erge T, Haw LC. PV in buildings for Malaysia: prototype solar house. In: Proceedings of 3rd world conference on photovoltaic energy conversion, vol. 3. 2003. p. 2358-61.

10. Anonymous, Equatorial sunshine: the Malaysia BIPV programme. Renewable Energy World Magazine 2009.

11. IEA-Trends 2015 in Photovoltaic Applications

12. Waldau, J., PV Status Report-2014, November 2014, European Commission, DG Joint Research Centre,

13. Macknick, Beatty, Hill, NREL, Overview of Opportunities for Co-Location of Solar Energy Technologies and Vegetation, 2013 